\title{
In Search of Community; Humanitarian Engineers and Circles of Friends
}

\author{
David R. Muñoz \\ Emeritus Associate Professor \\ Colorado School of Mines ${ }^{1}$ \\ Golden, CO 80401 \\ dmunoz@mines.edu
}

\begin{abstract}
Circles of friends (trust) as a means for indigenous community development have been actively encouraged in Colinas de Suiza, Honduras. This effort at enhancing longterm community resilience is the latest in a 10 year relationship that includes a water project and two school construction activities within the village of $\sim 10,000$ economically poor. These techniques were utilized in part to provide an example of communities in partnership for universities involved in developing educational programs around practically-based engineering service learning projects. To enhance community involvement, children were included in the development process through creative educational activities involving music, graphical arts and dance. The initial two-month experience culminated in a fiesta or celebration of community. Project evaluation has yielded several positive indigenous results; namely the construction of a dining hall, supported by the local community where poorest children are fed, and the formation of a locally managed credit union where the local people can place their savings and apply for microloans for microenterprise development. This project is further testament to the belief that humanitarian efforts are most effective when performed consistently within the same locations and where the entire community is invited to organize, identify, discuss and solve their own problems.
\end{abstract}

Index terms - circles, community development, community resilience, creative, humanitarian, humanitarian engineering, innovation, microenterprise, sustainability.

\section{Introduction}

This paper documents the culmination of a ten-year experience (2003-2013) between me, engineering students and the people of Colinas de Suiza, Honduras. Engineering design students were directly involved in an eight-year portion of this decade, but the relationship with the local people also included a small group of honors engineering and science students and a dozen or so teenage youth on a United Methodist church mission trip. The constant over this period has been my active involvement and that of the local leadership of Colinas de Suiza and the municipality of Villanueva.

Over this time period there were significant changes in engineering curricula to include service learning components at many universities across the globe. It was a time of discovery and interdisciplinary opportunity. This movement provided opportunities for the authentic

${ }^{1}$ Please use PO Box 733, Taos, NM 87571 for mail correspondence. 
engagement of students and faculty with the economic poor of the world. As an engineering professor I found it refreshing to read articles from anthropology and rural studies journals and seminal books on social justice to seek ways to more effectively work with a population lacking many basic needs.

I cannot imagine a more important element to include in the service learning educational process than the act of finding creative ways to actively engage the community in their own development.

\section{Physical Project History}

The details of the potable water project portion of this story are already in print elsewhere ${ }^{1}$. The reader is encouraged to seek that reference as it contains other articles that are relevant to the practice of service learning in Central America. Only a brief history is presented here.

This project began in May of 2003 with a meeting between Villanueva Mayor Jose Felipe Borjas and I to discuss a potential engineering project for senior level engineering students and the people of Colinas de Suiza, a village of 10,000 people that moved to this location after hurricane Mitch ravaged the region in October 1998. The Mayor was concerned with pit a latrine contaminating the ground water from which drinking water was being withdrawn in neighboring communities. I agreed to return with students to further investigate.

In the ensuing years several engineering student teams traveled to Colinas de Suiza, first to understand the most pressing needs of the local people, then to acquire information necessary for potable water system design and eventually to work with the local people and local elected officials toward system implementation.

This was a large project for a university professor and students to undertake. In the end it would involve the entire village of 1500 families, the municipality of Villanueva that was responsible for many other villages spread over a $240 \mathrm{~km}^{2}$ area and several NGOs.

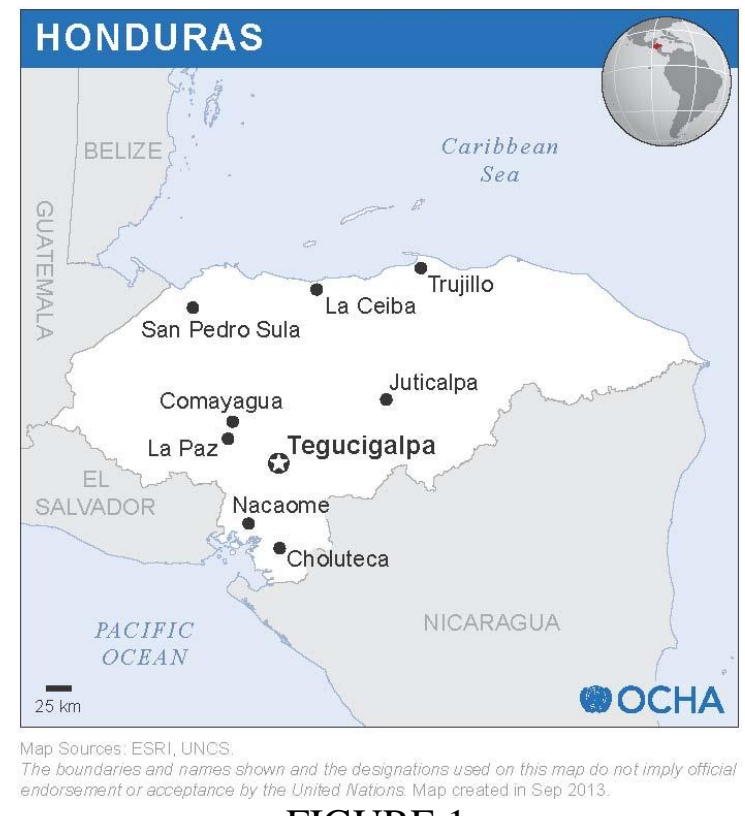

FIGURE 1

MAP OF HONDURAS (HTTP://RELIEFWEB.INT/LOCATION-MAPS; FOLLOWING THE CREATIVE COMMONS ATTRIBUTION UNPORTED LICENSE HTTPS://CREATIVECOMMONS.ORG/LICENSES/BY-NC/3.0/DEED.EN GB) 


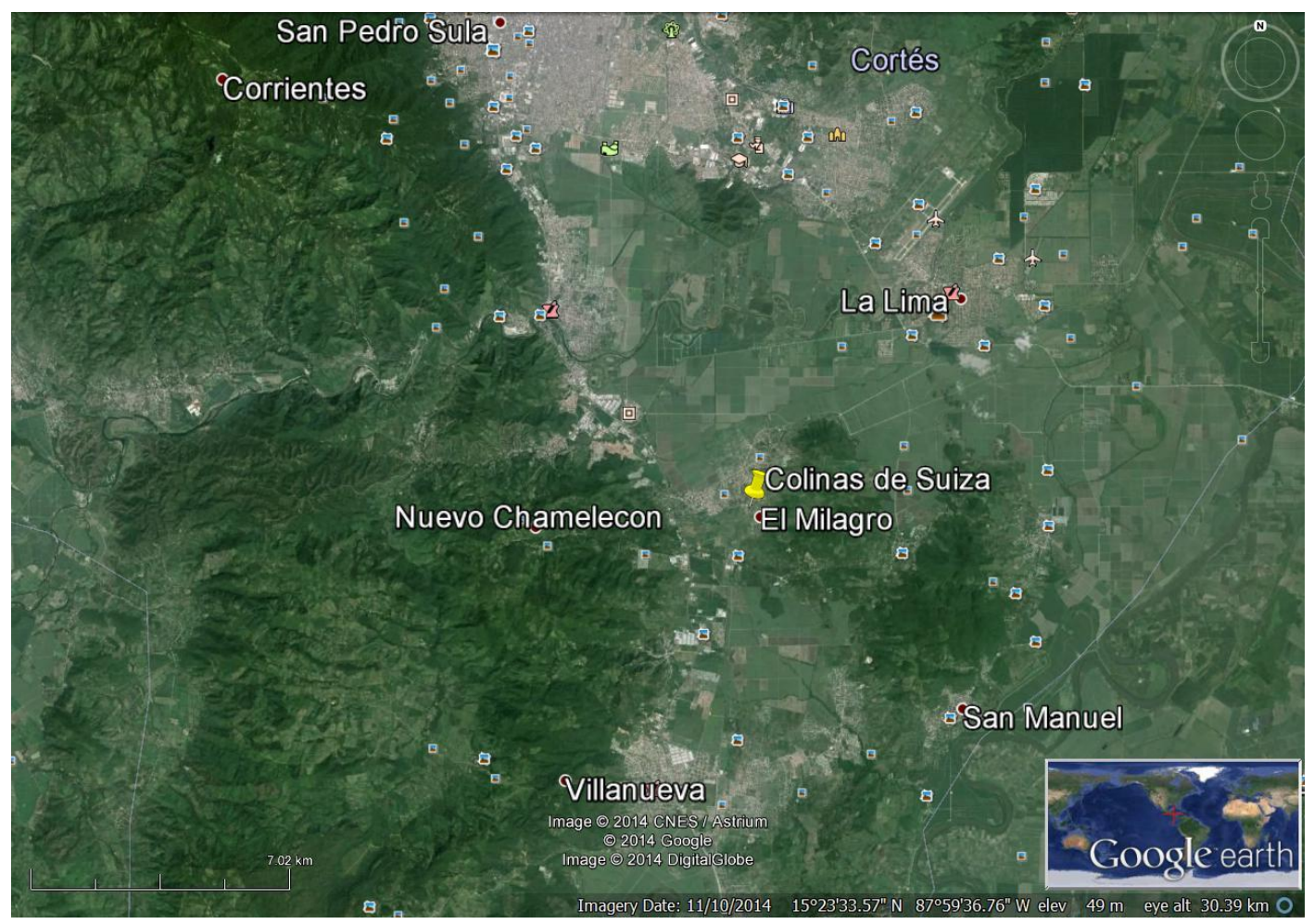

FIGURE 2

MAP OF THE MUNICIPALITY OF VILLANUEVA. (GOOGLE EARTH, 2014)

Water project cost estimates exceeded $\$ 1.5$ million. Though substantial efforts were made to raise these funds, this magnitude of funding could not be secured. However, we were fortunate to receive a major in-kind donation of 72 tons $(46 \mathrm{~km})$ of plastic pipe and fittings ${ }^{2}$, and funds ${ }^{3}$ to transport the materials to site. The people of Colinas de Suiza collectively paid for the 250,000 gallon water storage tank (with a cost estimate of over \$100,000). The municipality of Villanueva, through the water and sanitation department (Agua y Sanimiento de Villanueva, ASVI) ${ }^{4}$ paid for the $400 \mathrm{ft}$. deep well, the pump and secure pump house, along with the labor to bury the $3 \mathrm{~km}$ long supply line. The people also provided manual labor with supervision from ASVI to bury $40 \mathrm{~km}$ of water distribution pipe, so that each house would receive access to potable water.

A decade later from the first visit with Mayor Borgas, water was running in each home. Meanwhile the local leadership and I have been exploring ways to help sustain this and future projects. The purpose of this paper is to present results of the latest effort to organize the people into circles of friends (trust), with the goal of aiming the community toward greater resilience.

\section{Rationale for the current project}

Socio-technical Challenges

Along with the buried pipe, ASVI added over 100 pressure control valves in the distribution system to allow for maintenance and control the flow of water to different sectors on a particular time schedule. Since there is insufficient water to supply everyone with water $100 \%$ of the time, these valves were used to control the flows so that each family could expect the water to be 
available during specific times of the week ${ }^{5}$. Additionally, ASVI workers installed a number of brick boxes with concrete covers to protect the valves that were in more exposed areas near the road sides. In the ensuing months, several of the boxes were broken into and valves were stolen.

By this time the well house was completed and efforts were underway to connect the pump to the electrical grid. Unfortunately, thieves broke in and stole the copper wire from the nearest utility pole to the top of the pump discharge. During a second occurrence, the thieves broke through a steel reinforces concrete column that contained the 12 inch pipe exiting the well, built a small fire on the side of this now broken column to soften the 12 inch diameter plastic pipe and cut the copper wire leading to the submersible pump to take even more of the copper wire and presumably sell it for scrap. These acts elongated the project timeline and greatly increased the project expense.

The people who had worked hard (myself included) and invested their money to the water tank portion of the project became quite frustrated, especially with the valve thefts/destruction and asked the patronato (elected village board) to organize several meetings to vent some of this frustration. In one such meeting I asked a local pastor to read a statement from the Bible, "If anyone will not welcome you or listen to your words, leave that home or town and shake the dust off your feet" ${ }^{6}$. I knew that the people would relate to this simple message and sense the potential implications of this frustration. One man stood up and confessed, "I have taken one of the valves" and asked "should I return it". He received an immediate ovation from the audience. This admission of guilt and the public response was a victory for the community in that many people felt the frustrations and yet offered an immediate response for forgiveness. This was an indication that the people had begun to realize that this project belonged to them. If the project was going to survive, they would need to police their own neighborhoods and confront anyone bent on destroying the system (of/for the commons) for personal gain, or for whatever reason.

\section{Challenges to the Service Learning Component}

In 2003 service learning (SL) was a relatively new area of exploration ${ }^{7}$ within engineering education community in the United States. Several engineering service learning organizations had just formed and SL within engineering programs were being discussed around the globe. Students were driving much of the enthusiasm and personally I was seeking more proactive opportunities to create a more peaceful world.

An opportunity arose to respond to a request for proposals on a sizeable grant at our university that allowed the formation of a new service learning minor program. An interdisciplinary committee was formed to develop a curriculum that contained both technical and social science elements. Through our reading of the literature we became aware of the failings of past humanitarian efforts ${ }^{8} 9$. Engineering design curriculum and textbooks were limited to mostly technical means of achieving a design solution. There was an emphasis on the customer or client but the interactions between the engineering student and the client were cordial, distant and short-term. Trust was primarily based on the technical competence of the student engineer or the student/faculty team. We began to seek and accept opportunities to combine service learning with capstone design requirements. We learned through practice that these projects were much more complicated. We found that developing community trust is of paramount importance, depends on much more than technical prowess and takes time. Participatory research and design, although commonplace in circles of anthropologists or artists, were generally not emphasized in the engineering curricula. The Colinas de Suiza project was particularly challenging because it was so large ( 1500 families or 10,000 people) that none of 
the entities (people, represented by their patronato; municipality, represented by the mayor and officials in the water and sanitation department, and students and faculty from the university) could fund the entirety of an estimated $+\$ 1.5$ million project.

Another challenge that developed over this time period was related to security. Many locations around the world (such as Honduras) have been popular for student SL projects perhaps because of its close proximity to the US. Unfortunately over the past few years these areas have become quite dangerous ${ }^{10}$. In fact, violence in Honduras has reached an extreme (San Pedro Sula recently led the list of the most violent cities in the world ${ }^{11}$ ).

Time is also a challenging factor involving the international service learning projects. Due to the cost of travel and tight schedules of engineering faculty and students, the longest time available for getting to know the local people and developing a sense of trust was from one to several weeks per year. Over the years there was an additive effect for me and other faculty because we returned to the same village site. However, because students are only in the university environment for an average of four or five years, and are usually involved with these senior or graduate level projects for one or possibly two years, only a few students returned a second time to continue work with the same local people. For the student this was insufficient time to develop a deep relationship and consequently a deep level of trust with the people that they are there to help.

In spite of these challenges, I believe it is still worthwhile to seek opportunities to include engineering students in international SL projects. We are all connected on this planet, in more ways than we understand. The more meaningful experiences we can offer our youth in immersion experiences, the better. The US wields substantial power around the world. We need young leaders that are aware of how people live in various parts of the world and how to respectfully interact with them. However, as faculty leaders we should also exercise prudence with regard to travel security and rigor in travel preparation and on-the-ground awareness of the immediate surroundings.

\section{Circles of Friends (Trust)}

In January 2011, I travelled with colleagues and students to work with them in their service learning project in Trinidad de Copan, Honduras. Prior to going to the project site, the group spent a day near Tegucigalpa at the training site for Heifer International. Tim and Gloria Wheeler have been working with Heifer for the past forty years. Tim is an ex-patriot of the US and Gloria a Honduran. Gloria's sister, Norma Mejia, shared with the group her process for preparing the Honduran poor, predominantly women, for projects like the service project on which we were about to embark.

Norma indicated that she begins by encouraging the villagers to form small circles of friends (circulos de amigas). Predominantly women, these would be people who already knew each other and had already established some sense of trust for one another. She would encourage them to embark on a small project, perhaps a microenterprise in which the women would make something (such as tortillas, or small pieces of jewelry) that could be sold locally. Norma would spend time working with the circles until nearly the entire village had at least a family member involved with a circle. After the circles were established and producing a product, she would gather the circles together into a single meeting and begin discussing the possibilities for a much larger housing project. At this point the project transitioned and Tim and Gloria would become involved and would coordinate work student teams from the outside to help with financing the housing project and providing labor for a week or two. Each student was required to pay \$200 
for access to the service project. This money was used to buy basic building materials such as bags of cement, gravel, steel rebar, lumber, wire, fasteners and roofing material. The villagers benefiting from the housing project were also expected to work on their own homes. Local men and women who had benefited from a previous building project would be asked to serve as foreman for this new project. He/she would train the current project beneficiaries on how to make concrete block from the raw materials and also serve to train the students and faculty how to mix the mortar, lay the concrete block and cut and tie the steel rebar.

I was impressed with the process that the Wheeler/Mejia team used to initiate a large project and began to wonder if I could incorporate a similar project organization to Colinas de Suiza (post water project), the village that I had been working with for the past seven years.

In 2008 I traveled to Honduras with a colleague and graduate student to interact with Colinas de Suiza elementary school children and their teachers. This was a part of a GK12 research/educational enrichment program that placed US engineering and math graduate students in US middle school science classes. One aspect of the program was to take a few graduate students to international locations to interact with students and teachers. I observed as the graduate students prepared and gave talks to the Colinas de Suiza 5th and 6th grade classes. I noticed that the children were quite engaged and eager to meet the new foreigners. However, I wondered if we might offer an opportunity to have the 5th and 6th graders become more actively involved by asking them to develop some sort of presentation for us, so that we could better understand what they had been learning in their school. We mentioned this to their teachers and they agreed to talk with their students. Since we were there for only a week or so, the children only had a day to prepare. We returned to observe their presentations and were quite impressed. Most were poster presentations but one used drama to retell the famous Aesop fable of the blind men who each felt different parts of the elephant and yet mistakenly identified the animal as something else. The graduate student in Mathematics who traveled with us was particularly impressed with one of the presentations on a mathematical operation that was performed in a unique way. Others have written about the power of encouraging creative participation ${ }^{12}$ and its connection to human motivation ${ }^{13}$.

I was moved by this experience and wanted to combine the idea of circles with children's involvement in creative activities in a project for Colinas de Suiza as a way to (in the short term) enhance community engagement and (in the long term) community resilience.

In 2010 I was asked to serve on the advisory council of the Fetzer Institute ${ }^{14}$. Fetzer's mission is to "promote an awareness of the power of love and forgiveness in the emerging global community". Members of the engineering advisory council were challenged in the process of learning/establishing how love and forgiveness was or could be used in the practice of engineering. In late $2011 \mathrm{I}$ offered a proposal to the engineering council of using circles of trust ${ }^{15}$ in Colinas de Suiza as a way to potentially begin a humanitarian engineering project. The idea was approved for consideration by the Fetzer board and a proposal was prepared to make the case. Funding was approved. However, I was not able to bring the funding through the university. Since I was planning to the include children, there was a perceived risk associated with human subjects research and I was denied access to my home university. I tried to work with a second university through their department of psychology and was similarly discouraged. This time because the person I interacted with had difficulty with the word "love" in the proposal. A third university would have allowed the funding to pass through their research system, however by that time I felt that I understood the challenges well enough to form a 
limited liability company (LLC) and with Fetzer's help, do the project as a consultant outside of the auspices of the university.

Upon returning to Honduras, I hired Norma Mejia and her colleague Teresa Lopez (of Fundacion Simiente) to initiate the circle leadership training. Norma and Teresa lived in Tegucigalpa and regularly travelled to Choluteca (located in southern Honduras), which is a four to five hour drive from Colinas de Suiza. This was too great a distance to provide the almost daily interactions that I was looking for. Therefore, because of their proximity to Colinas de Suiza, I also hired two local Honduran Sociologists, one (Jorge Lara) who would serve as a project evaluator and the other (Claudina Reyes) to work actively with the people in community development. They each had over 25 years of experience in rural community development projects and were also adjunct faculty at the San Pedro Sula branch of the University of Honduras (Universidad Autonoma de Honduras, campus Valle Sula). Erlinda Villalobos, a Honduran social worker who already had experience in working with Fundacion Simiente and lived near Colinas de Suiza was hired to work daily to support the circles through December 2013.

Over the years I had maintained communication with the Colinas de Suiza elected leadership (patronato) and when I explained the plan to them they became quite interested and felt that this was exactly what the community needed at that time. I asked them to select people that they thought would have an interest in circle leadership and that had the following characteristics:

- spirit of service

- value diversity

-would not dominate the conversation

We invited the interested people to participate in the inaugural circle meeting with Norma. Approximately 25 people arrived and Norma spent a Saturday and Sunday guiding them through the process of forming circles. In one of her presentations, she mentioned the idea of microenterprise. Suddenly, the idea of community circles made more sense to the attendees. From that point on, the idea of circles became synonymous with microenterprises.

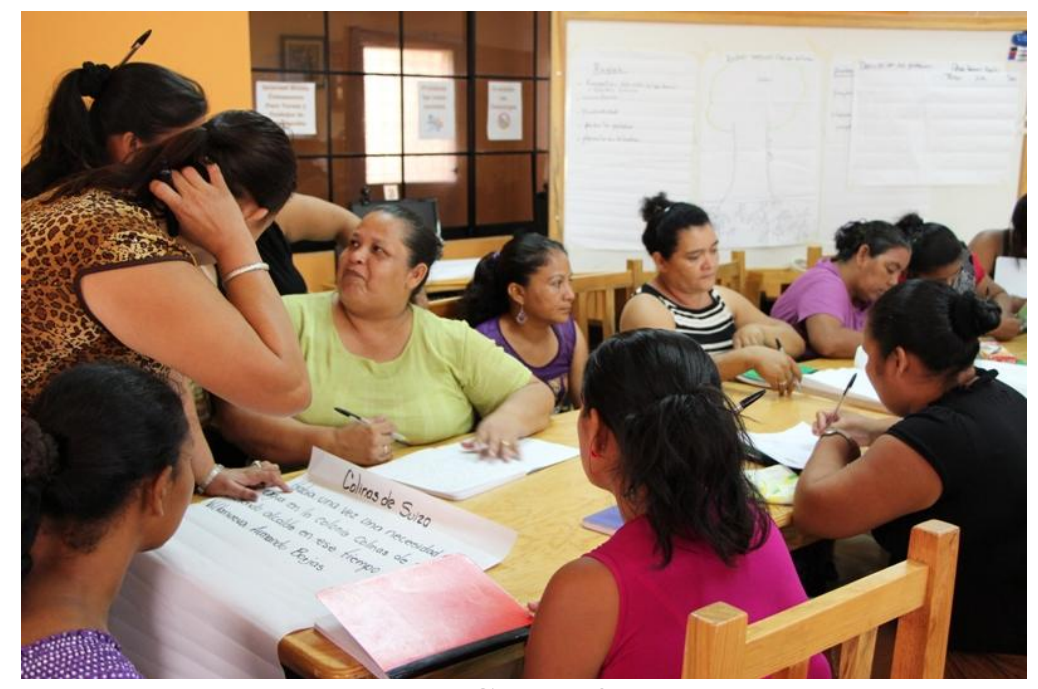

FIGURE 3

LEADERSHIP TRAINING FOR CIRCLES OF FRIENDS 
Twenty five small circles (microenterprises) were formed. Because I had not anticipated the formation of small businesses, I had no budget for seed money to help get these small businesses off the ground. However, we learned about a local microloan bank called Empresa de Servicios; Multiples Unicas en Accion. This small microloan bank was an association of women that received their seed funds from CARE International and would make loans of L.5000 ( \$250) that would have to be paid off in 6 months; otherwise there would be extra interest payments required. We invited the Director of the program to come to one of the circle leader meetings to explain the process. The people appeared reluctant to go into debt as they were not generally accustomed to the idea. Nonetheless they were made aware of the possibility.

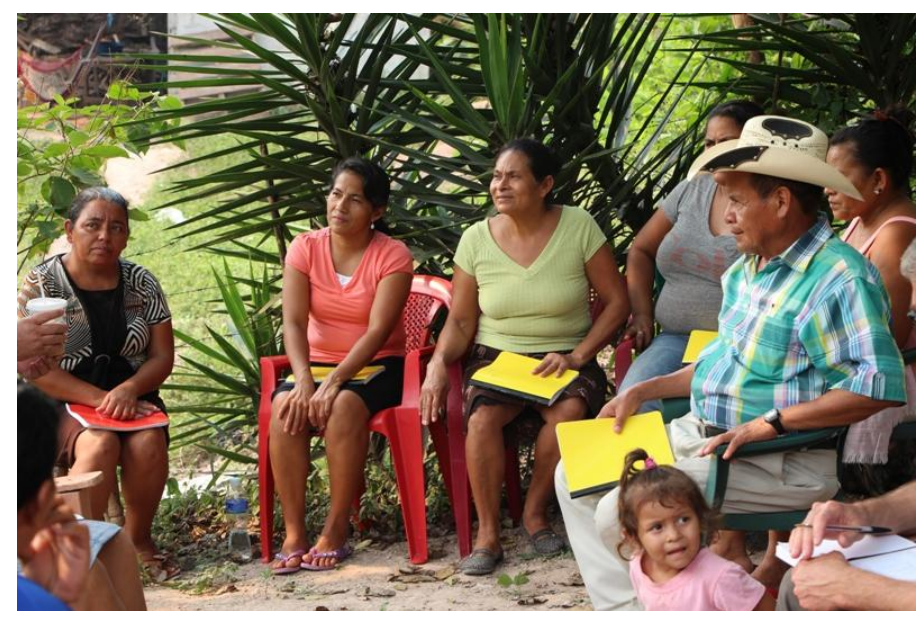

FIGURE 4

FIRST CIRCLE MEETING WITHIN THE VILLAGE COLINAS DE SUIZA

I was able to locate several hundred dollars within the budget that could be used to provide some seed money for a few of what I felt were the more promising groups that needed key tools and materials to get started. This idea however, was challenged by the sociologists. Because there were not sufficient funds to go to all of the circles that were forming, they indicated that it would place social strain between the circles who received monetary support and those who did not. While I understood their concern, I still wanted to help the more promising circles. Therefore, I asked each circle to write a short proposal describing their proposed or existing business including materials and equipment that they already had in place and the purpose for the proposed funds. This evidence allowed me to more objectively select those circles that I felt had a better potential for success.

One of the circles had a very strong team of women seamstresses. Since another aspect of the project was to include the children in creative exercises, I asked and paid this circle to sew 10 pairs of folkloric dance regalia for the children of each of the three schools (30 pairs total). As we began to plan for the fiesta, I engaged and paid the piñata circle to make piñatas to be used for the children's enjoyment following the other fiesta activities. Additionally, the two tortilla circles were asked and paid to make tortillas for the fiesta. These decisions effectively met two objectives of the project; enhancing circle formation and contributing to children's creative participation in community activities. 


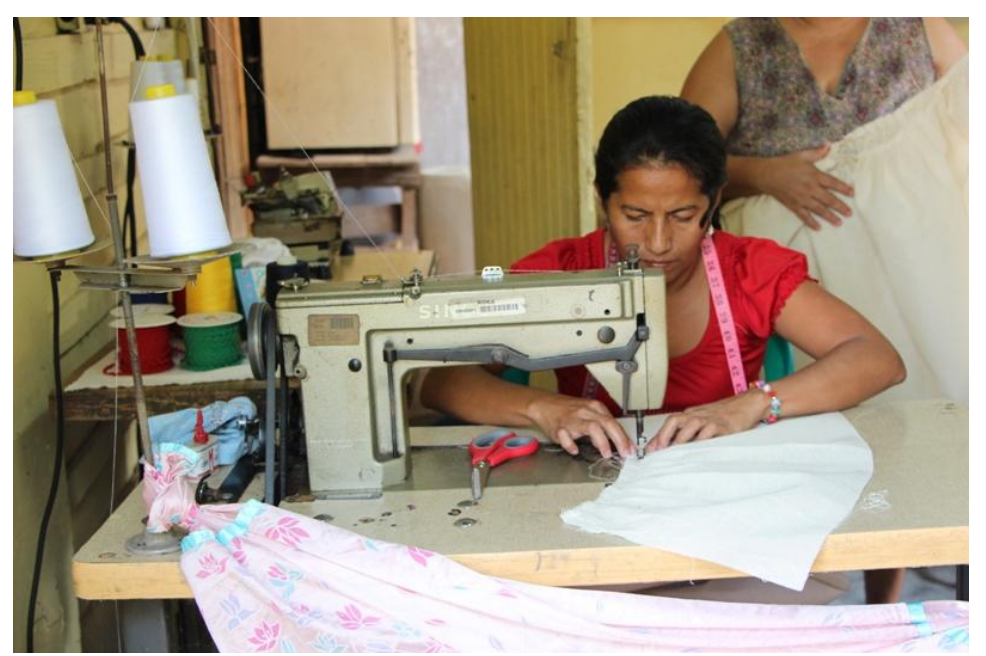

FIGURE 5

MEMBERS OF THE SEWING CIRCLE AT WORK

The circles were maintained through weekly meetings of the leadership with the Sociologist and project evaluator in addition to their meeting to complete their own circle tasks.

To engage the community children, I was able to enlist the help of Jose Luis Gutierrez, a visual arts and music instructor from the local high school, Instituto Villanueva to work with 5th and 6th graders in graphical arts and music. I first had to convince his supervisor (Rene Berrios) that the project was worthy of Jose Luis suspending his high school classes for three mornings a week over a five week period to allow him the time to work with the 5th and 6th grade children of Colinas de Suiza. None of the three elementary schools within Colinas de Suiza had previously incorporated visual arts into their classes and only one school had previously included music into their curriculum, though at that time they no longer had the resources to continue teaching music.

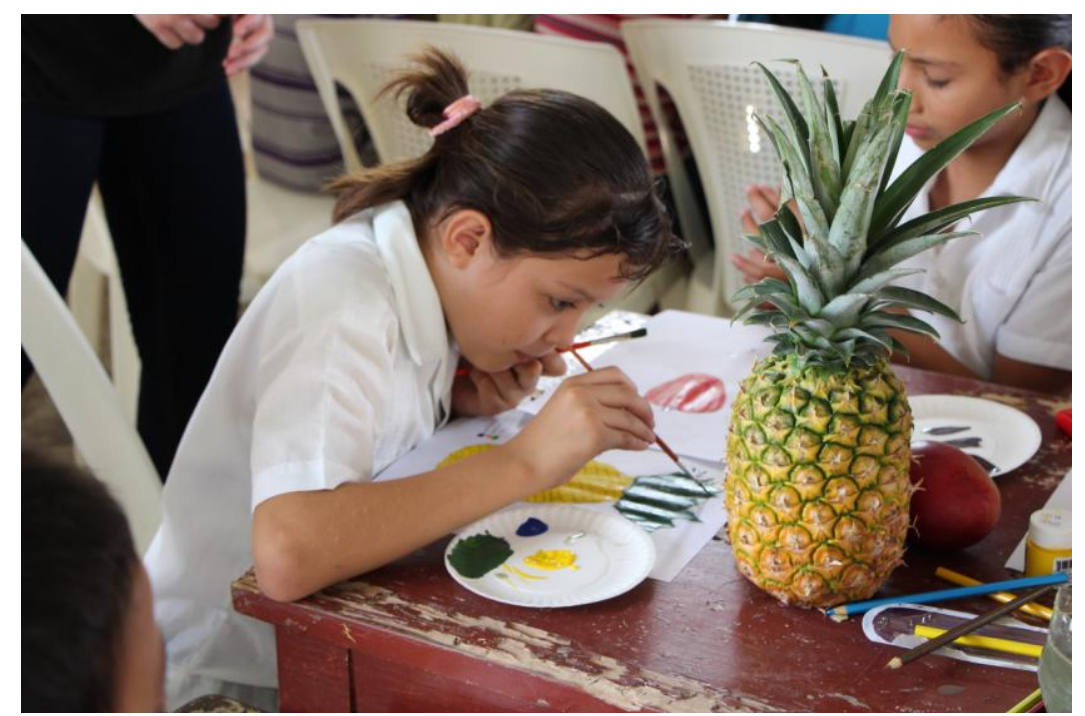

FIGURE 6

CHILDREN LEARNING TO DRAW, MIX PRIMARY COLORS AND PAINT STILL LIFE 


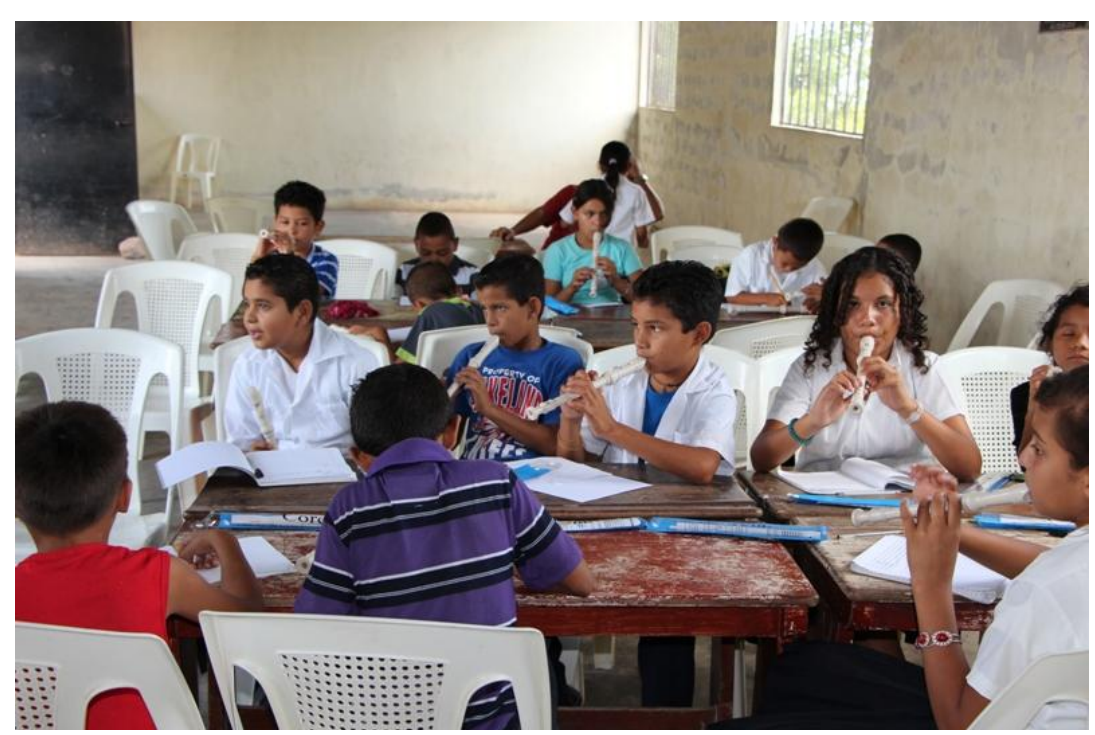

FIGURE 7

CHILDREN LEARNING TO READ MUSIC AND PLAY THE RECORDER

During the weekends I engaged Miguel Munoz to teach folkloric dance and Jesus Chinchilla to teach modern dance to interested children. They in turn engaged teenage youth from the local youth center to help teach the children.

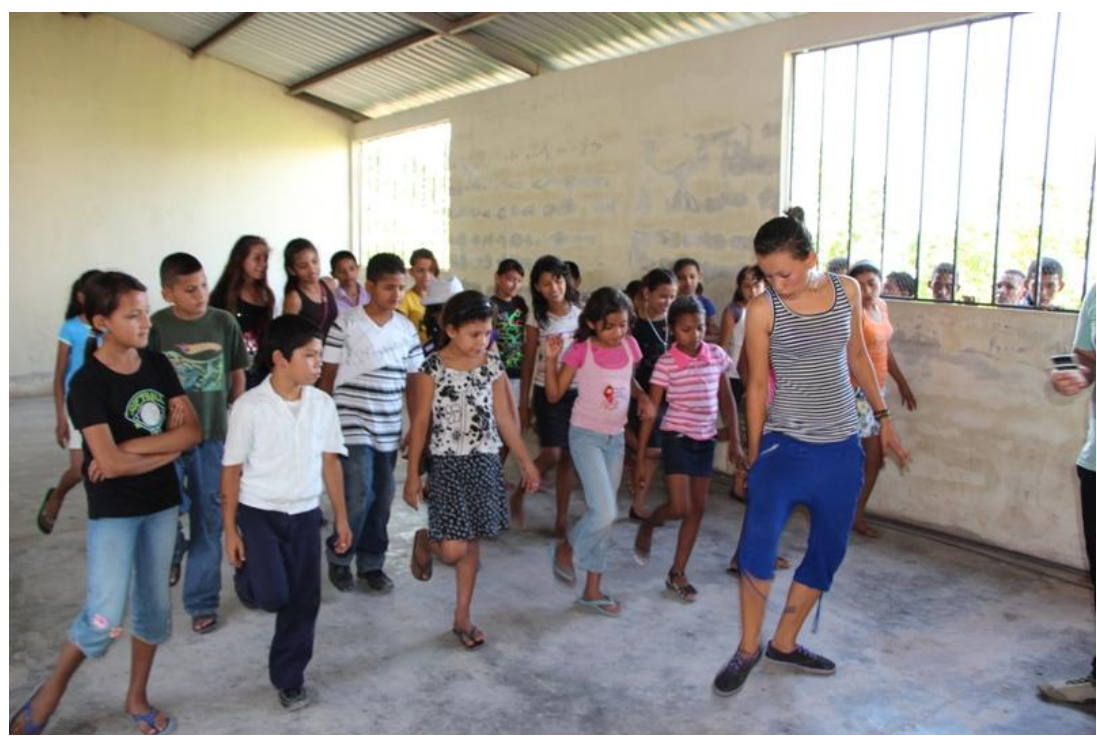

FIGURE 8

CHILDREN LEARNING TO DANCE, BEING TAUGHT BY LOCAL TEENAGE YOUTH

This two month portion of the project culminated in a fiesta or celebration of community, in which the circles would present their products and the children would present their dances and artwork so that the entire community would have the opportunity to see the capacity that existed within their own community. I produced a video of these activities for interested readers to share with their students and colleagues ${ }^{16}$. My hope was that the community would find reason to periodically celebrate in a similar fiesta. 


\section{RESULTS}

In December 2013 I have received a final report from Jorge Lara, the project evaluator that details his impression of the project outcomes nearly 7 months after the fiesta. In addition, I have maintained contact with personnel in the department of social services within the Municipality of Villanueva, who have remained in contact with the local people of Colinas de Suiza.

My view of the context as a North American humanitarian engineer encapsulated my own values and perspective, which was likely different than those of the local people, even though I have a Honduran father (a legal immigrant to the US) who was born and raised in another village not far from this one. Therefore, it was imperative to include an external evaluation to help clear the fog of a context likely different than that of the local people. The external evaluation yielded an opportunity for me to understand the externally perceived project benefits and challenges that I may not have otherwise understood.

This evaluation process also allowed the community the opportunity to be critical of themselves and the local authorities and institutions. Though Jorge they evaluated their status and made appropriate recommendations to improve their future.

Jorge made the following specific comments at the end of his final report ${ }^{17}$ (translated from Spanish to English by the author).

\section{Major Achievements in the Water Project}

The people in the community regard the continuity of the water project in the community as a valuable asset and that most families are now connected to it $^{18}$. In addition they (ASVI) have created a reduced easy payment method for the few families who cannot yet afford the normal (monthly) service fees paid. It is believed that all have a basic right to connect to the water system.

The main achievements identified are:

(a) The health of family members especially children has improved.

(b) Families save a lot of money. Prior to the water project completion, the water was (6 times) more expensive.

(c) Women now spend more time with their children as they no longer have to go long distances to get water.

(d) In the typical community house, the people can now have gardens, food crops, such as plantains, bananas, and other fruit as well as raise chickens and pigs, and they have water in their homes.

(e) There is a high level of approval to the municipal authorities and a high appreciation to the Fetzer Foundation $^{19}$, especially with Dr. David Muñoz.

\section{Organizational Problems that Persist within the Community and the Causes and Solutions that the Community has Identified}

Two of the four committees organized as a result of this effort (the Committee for the protection of the environment and risk prevention, and the Committee for education and culture and mental health) have not managed to consolidate and have not developed any of the priority activities.

The following weaknesses were detected in the community, which is impeding the development of the planned activities. 
(a) Neither training plan nor minimum resources are available to help promote the committee activities.

(b) A lack of follow-up activities (perhaps) caused by the absence of an operational plan.

(c) Little participation of young people in the meetings and activities of the community.

(d) The institutions which help manage or coordinate these type activities are inconsistent in the follow-up; this is the case with the Municipality of Villanueva and the local Red Cross.

(e) The cooperative requires strengthening with training in cooperation, regulatory accounting and administration (such as a file system to save the records).

(f) The circles of trust require further training in quality in production, marketing and administration, to make successful use of the loans when they are available.

The following solutions have been proposed by the people of the community.

(a) Evaluate if it is worth continuing the development efforts of the community under the mechanisms defined in the plan for the development of the community.

(b) There is a need for a small community development project, utilizing the experiences to date.

(c) It is important to have financial support for the strengthening of activities.

(d) There is an urgent need to make a campaign for the prevention of dengue and natural disasters such as landslides and diseases caused (in part) by the lack of sanitary sewer system. Already there is a perception that the community is highly vulnerable to these problems.

(e) We need to develop a project specifically for the population of young people in order to motivate their integration to the participation and away from problems such as drugs, teenage pregnancy and sexually transmitted diseases.

(f) To supplement the water project, it is necessary also to require that the company (ASVI) manage the periodic cleaning of the tank and the purification of the water, it is also necessary to manage a project of sewerage or toilets connected to septic tank ${ }^{20}$ to improve community health.

\section{Project Evaluator Conclusions}

(a) The greatest successes of this project are that (even with the aspects that must be improved) the community is very satisfied with the service of drinking water and with effort and initiative of a group of entrepreneurs in the community that created and proposing to operate a credit union. There are also good results of the organized efforts within two of the four newly formed committees; early childhood care and basic sanitation and health care.

(b) The experience of Colinas de Suiza shows the effectiveness of theory proposed by Amartya $\mathrm{Sen}^{21}$, on the use of human capacity for the solution to poverty, as here, the development of human capacities have been essential in the formulation of incentives for families to overcome their condition of poverty, which makes it an example to be followed by other communities.

(c) It is important to highlight the high level of participation of women in the community in this community experience; they are the most dynamic element of the process, because they are the most specific, and they are always present.

(d) The permanent accompaniment and solidarity is without doubt the explanation for such high levels of community participation achieved by this project. In fact, it is uncommon for the 
poor in Honduras to be involved with the same motivation and enthusiasm that have been observed in Colinas de Suiza.

(e) The Community already has an account manager within the development team. This team has the training and the necessary support to take the lead in community development;

(f) Of the 38 circles of trust that were recorded at the beginning of June of this year (2013), 24 have opted to be grouped in a credit union with the hope of creating their own capital that will help grow and develop as small businesses and entrepreneurs grow and develop. It is very likely that the rest of the circles will become motivated to integrate because the cooperative only started with 12 and after a month had already 24 new partners. The cooperative is also open to other people in the community even though they do not belong to circles of trust. For instance those working as employees in the local factories also see the possibility of savings to alleviate future problems in the family.

(g) Within the academic Honduran Social Sciences environment, there has not previously been community experiences of urban development with the innovative elements used in this project. This will no doubt be the starting point for publications, academic discussions and new knowledge for the university education of sociologists, anthropologists, historians, and social workers.

(h) Without a doubt one of the major contributions of this project are the values of love and forgiveness. This is especially relevant in a society as violent and tumultuous as the current Honduran society. Perhaps some people, who have no expertise in this area, believe that it (love and forgiveness) is a matter of pure emotion, but for those of us who have been immersed in the midst of the people in the community, we can see how these principles have achieved social bonds of solidarity and coexistence.

(i) An important element to emphasize is that the development committees, managed to develop and maintain significant activities [such as the study to determine the level of presence of mosquito larvae in the family water tanks and recently constructed common school dining room for the small children (built by people who are also part of the cooperative)] illustrates a direct relationship between expectations of improving the quality of family life and community improvement. People are learning that one determines and stimulates the other.

\section{Evaluator Recommendations}

(a) In accordance with the views expressed by the people of the community, it is important to give continuity to the immediate proposal of "Development Plan", fortified by community involvement to strengthen participation in all its aspects.

(b) Any external support that the community receives should be based on respect for the past community achievements and should be aimed at strengthening the achievements and promoting initiatives. Giving help that promotes dependency incites paternalism which truncates the experience of a socially active community.

(c) The circles of trust, are integrated by enterprising individuals who already have knowledge of their own accumulated experiences and their daily struggle to survive, any person or institution that perform community intervention in this respect should be based on the practice, and should not impose agendas and institutional policies.

(d) It is a priority to support the strengthening of the cooperative initiative driven by some of the circles of trust. This may be achieved through the consolidation of some circles in the medium-term; 
(e) In view of the fact that the Colinas de Suiza experience contains innovative elements important to the development community, it is recommended that you systematize the experience to be replicated in other poor communities of Villanueva, and throughout the country in general or in the Central American region where there is a great lack innovative ideas to work on the theme of poverty;

(f) Special attention should be given to track the changes over time that will occur in the quality of life of the families as a result of the credit union and the consolidation of their respective productive projects.

\section{Conclusions of the Principal Investigator}

Circles of friends (trust) provided an effective tool to enhance community engagement and self discovery. These techniques have already been successfully implemented by the Mejia/Wheeler team to initiate large projects on Honduras and, in the case illustrated on this paper, this technique has succeeded after following a large engineering/construction project. I am convinced that in general some form of community engagement/self discovery techniques are an important part of an effective university educational program in service learning.

Developing trust is absolutely necessary for effective community engagement and requires time to achieve. For this project achieving trust has required continuous communication over a ten year period. In a large impoverished community where the major mode of communication has been orally one-on-one, this has been a significant challenge. The circles of friends technique provided an effective means for communication because the circle leaders, who were generally better connected and had a cell phone, easily disseminated the information to their peers. Likewise, using these circles communication links, information was propagated from the local people to me and the community leadership.

In spite of the challenges to do so, I believe it is important to engage the children and young people in these community-wide projects. It was indeed a challenge/need recognized by the project evaluator. Children and youth are the future of the community and should be included as much as possible in community activities. Additionally, engaging the youth will also naturally enhance the engagement of their parents.

Although Jorge did not mention these examples in his summary, I am aware of several young people involved with the circle movement. For example one teenage youth worked with her parent, an older sister and neighbors to start a small circle making and selling piñatas. Another circle was begun as a continuation of a senior-level university business class project by a 20 year old member of the community. In fact, I was so impressed with her business plan that I decided to help her by purchasing a propane gas stove that she needed to realize her small ice cream business. To make the business a reality, among other things she will have to overcome local approvals that assure sanitary conditions in the food manufacturing process. In return for the stove that she received she agreed to teach other interested community members how to develop a business plan so that they too could benefit from her newly gained knowledge.

It is a rare opportunity for a humanitarian engineer to work on a project embedded within the inner and community-wide space of love and forgiveness that embraces indigenous community development techniques and benefits from a project evaluation a decade after beginning a major engineering project. I am deeply thankful for this experience. 


\section{Acknowledgements}

This unique opportunity would not have been possible without the support of the Fetzer Institute along and that of numerous Hondurans within the community of Colinas de Suiza and municipality of Villanueva. Specifically, I would like to thank Don Francisco Mazariegos and Doña Reina Reyes of the Colinas de Suiza Patronato and Dr. Walter Perdomo (Mayor) and Manuel Edgardo Muñoz Garcia of the Municipality of Villanueva.

\section{REFERENCES}

${ }^{1}$ David R. Munoz, "In Search of Sustainable Community Development Through Practice: Sustainable Potable Water Project in Colinas de Suiza, Honduras," in International Volunteer Tourism; Critical Reflections on Good Works in Central America (New York: Palgrave Macmillan, 2013) 125.

2 Plastic Pipe and Fitting Association, http://www.ppfahome.org/ (accessed December 17, 2014)

${ }^{3}$ Food for the Poor, http://www.foodforthepoor.org/ (accessed December 17, 2014)

${ }^{4}$ ASVI, a public department under the auspices of the Municipality of Villanueva, now collects a fee for water system maintenance and consequently the people feel obliged to make requests for system maintenance.

${ }^{5}$ This process of sharing the water resources so that water availability to each home is discontinuous is generally accepted throughout Latin American communities. For this reason many homes will have one or several storage tanks that are used to store water when it is not readily flowing on-demand into the home.

${ }^{6}$ Matthew 10:14, The Bible (New International Version).

${ }^{7}$ Angela R. Bielefeldt and Joshua M. Pierce, "Service Learning in Engineering," in Convergence; Philosophies and Pedagogies for Developing the Next Generation of Humanitarian Engineers and Social Entrepreneurs (State College, PA, IJSLE, 2012), 24. (can be found at https://www.engineeringforchange.org/static/content/Learning/IJSLE_Book.pdf, accessed December 17, 2014)

${ }^{8}$ Paolo Freire, Pedagogy of the Oppressed (New York: Continuum, 2009), 60.

${ }^{9}$ David Rieff, A Bed for the Night; Humanitarianism in Crisis (New York: Simon and Schuster, 2002), 76,77 .

${ }^{10}$ Katherine Borland and Jeff Boyer, "International Students and Volunteers amid Rising Violence: The Challenges of Honduras," in International Volunteer Tourism; Critical Reflections on Good Works in Central America (New York: Palgrave MacMillan, 2013), 141.

${ }^{11} \mathrm{http}: / / \mathrm{www} \cdot$ businessinsider.com/the-most-violent-cities-in-the-world-2013-11?op=1 (accessed December 17, 2014).

${ }^{12}$ Joan M. Erikson, Wisdom and the Senses; The Way of Creativity (New York, W.W. Norton, 1988), 13. 
${ }^{13}$ Teresa Amabile, Creativity in Context (Boulder, CO 1996), 5.

${ }^{14} \mathrm{http}: / /$ fetzer.org/ (accessed December 17, 2014)

${ }^{15}$ Tracy A. Thompson, "Circles of Change," Stanford Social Innovation Review, Fall 2011, 42-47.

${ }^{16} \mathrm{http}: / /$ vimeo.com/user21635178/review/76428013/13304bf422 OR https://www.youtube.com/watch?v=f4MsNEXN1cw (accessed December 17, 2014)

${ }^{17}$ Jorge Lara, Comunidad de Colinas de Suiza, Municipio de Villanueva, Departamento de Cortés, Honduras, Centro América; INFORME FINAL DE EVALUACION, Proyecto "En Busca de Comunidad" Final Report, November, 2013.

${ }^{18}$ Shortly after arriving in Honduras in 2013 I asked the patronato if they knew of anyone who was not connected to the water system. I learned of two single mothers who were not connected because they could not afford the connection fee (now set by ASVI at L.2500 $=\$ 125$ ). I spoke with ASVI and the patronato to see if exceptions could be made for the desperately poor and they said yes. It was never intended by anyone that families would not be able to connect because they could not afford the connection fee or monthly payments. These two families were connected prior to my departure. I was assured that ASVI will allow the poor to provide a few hours labor a week to offset at least some of the fees.

${ }^{19}$ The Fetzer Institute had no involvement with the development of the water project. Rather, the water project was accomplished (in addition to those already acknowledged) with the support of the William and Flora Hewlett and the Shell Foundations and the 2005 Daimler-Chrysler/UNESCO Mondialogo Engineering Award.

${ }^{20}$ A substantial effort has already been made (2008) to encourage the local populous to consider composting toilets as a sustainable solution. Honduran efforts in "conventional" central collection systems are believed financially beyond reach. The composting toilet effort failed because it is not socially acceptable. This is a very difficult solution for an outsider (who does not use a similar technology in her/his own home) to successfully encourage. Perhaps success is more likely through education by their Oaxacan neighbors to the north http://www.sarar-t.org/ (accessed December 17, 2014).

${ }^{21}$ http://en.wikipedia.org/wiki/Amartya_Sen (accessed December 17, 2014) 